\title{
The Research of Labor Relations of Chongqing Electronic Enterprise
}

\author{
Zhan Juan \\ Chongqing Technology and Business University
}

\begin{abstract}
With the adjustment of industrial structure, Chongqing as industrial transfer station, have attracting a large number of electronic manufacturing firms to Chongqing. Electronic enterprises as labor-intensive enterprises, with large employment transfer capacity at the same time, also brought new labor relations and labor protection problems, such as forms of employment and labor relations are more complex, reversed transmission enterprise employees are over loaded, etc. Aiming at the existing problem of electronic enterprise, the author from the aspects of enterprise, government and laborer three party forward the path and method of dealing with contradiction.
\end{abstract}

Keywords: Electronic enterprise ;Labor relations ;Labor protection

\section{The present situation of Chongqing electronic enterprise development}

Chongqing in 2008 awarded the title of national high-tech industry center. "information industry", as the coastal areas of industrial transfer station, provides policy environment for its formation industry base cluster development .According to statistics, Electronics and car industry increased by $22.9 \%$ and $20.7 \%$, respectively, weighted more than $60 \%$ of the city's industrial growth, the contribution of the present electronic, automobile "two-wheel driven" two big industry, equipment, materials industries such as "multi-point support" development pattern.

According to the Chongqing municipal bureau of statistics released by the 2010 statistics bulletin of the national economy and social development in Chongqing, according to the electronic information industry in 2010 total output value was 40.09 billion yuan, an increase of
$48.1 \%$, only $4.4 \%$ of the gross value of industrial output over the scale. The proportion of Electronic information industry output value reached $23.7 \%$ in 2013, automobile and motorcycle industry become the pillar industry. Municipal government by preferential investment policies successively import notebook brands such as HP, Acer, and Foxconn, Inventec, Quanta, New notebook computers those foundry enterprises in Chongqing, by the end of 2013, 817 in Chongqing has been signing pen form a complete set of electric enterprises, total agreement worthy for 125 billion yuan. Enterprise implementation have been put into operation in 2013 output value 49.3 billion yuan, increased $47.6 \%$ from a year before, in which 59 new laptop accessory enterprises above designated size. The rapid development of electronic business, have a big role to create employment, the size of the above communication equipment, computer and other electronic equipment manufacturing enterprise workers, the average number of labor increased from 2.02 million in 2009 to 14.55 million in 2013.This has created thousands of new jobs, increasing employment opportunities, affect the proportion of the total supply and total demand, is conducive to improve the antagonism of capital and labor relations, to promote the construction of harmonious labor relations. However, foreign capital enterprise, due to cultural differences, cause a series of labor relationship problems.

\section{The analysis of the main problems of electronic enterprise labor relations and the reason}

\subsection{The main problems of electronic enterprise labor relations \\ Chongqing electronic enterprise mainly exists in the form of electronic manufacturing foundry, still belongs to}


the labor-intensive industries. Labor-intensive industries use cheap labor to exchange for the largest economic benefits for pursuit, and foundry enterprise is affected by upstream enterprise management system, the employee's harsh Taylor's scientific management mode. Foxconn in order to implement the standardization production. Emphasize the work efficiency and strict censorship makes the contradiction between workers and employers are increasingly acute.

\subsubsection{The labor dispatching employment form is not standard}

Labor dispatch as a job-creating measurements is introduced to our country has more than 20 years of history, mainly plays the function of the following aspects: promote the organization of labor flow; Better solve the problem of temporary and seasonal high labor costs; To solve the problem of frictional unemployment of youth workers; Solve the authority institution personnel outside the establishment of basic labor rights and interests protection issue. Bring the benefits of labor dispatch so that electronic enterprise, due to the large labor demand, staff liquidity, in order to reduce the cost of recruitment and management tend to put this part of the outsourcing to the labor dispatching company, by using labor dispatching workers during labor.

On January 24th, 2014, the ministry of human resources and social security of the People's Republic of China issued the interim provisions on labor dispatch indicate the project unit can only be temporary, auxiliary or substitute job positions using dispatched laborers, and use the number of dispatched laborers shall not exceed $10 \%$ of its total. In Chongqing $\mathrm{X}$ computer company, uses more than ninety percent of the dispatching workers as its frontline employees, that offers employees free flow.

\subsubsection{Collective labor contracts, collective negotiation} become a mere formality

According to statistics, 2012 cases in Chongqing to accept the case, the collective labor dispute cases accounts for only $0.35 \%$ of the current case acceptance, collective labor dispute laborer party number accounts for $6.76 \%$ of all workers party number. The effect of the collective bargaining did not play an important role. Enterprise adopts the system of collective bargaining, passively signed an agreement, in the practical implementation of no performance of the agreement, industries transferring the interests of the labor market to the western part, cheap labour supply is adequate, employees are lack of voice, etc led to this system is only on "paper". The phenomenon of the heavy, light negotiation has raised the purpose and meaning of collective negotiation.

\subsubsection{Form of employment, and labor relations are more complex}

This mainly for the enterprise employee forms and more diverse sources of employment. In electronic enterprise, both enterprise direct hiring staff, have labor dispatching company dispatching workers, seasonal workers, and the government's commitment to providing labor, such as technical school students to participate in the practice so as to graduate. The foreign capital enterprise staff both in the mainland, including Taiwanese management team. Both belong to the labor law and labor contract law regulate the labor relations, also have temporarily not clear applicable labor law, labor contract law regulate other employment relationship, once appear problem, solve the difficulty will increase.

\subsubsection{Employees with different rewards phenomenon}

Chongqing electronic enterprise, the foreign capital enterprise especially taiwan-funded enterprises accounted for a big, rich labor market environment. But because of the change in regional Taiwan-funded enterprises in mainland workers there is a gap and Taiwanese employees' salary and promotion space. X computer company, for example, has detailed job promotion system, the general staff into the enterprise first start from the help tube division, one to two years to tube division, then 2 - a specially - assistant manager - senior manager - the manager - such as deputy director of the layers and layers of promotion. But most Chinese nationals employees can rise to the position of 
manager and then stop there, the Taiwanese employees is not restricted, in this type of enterprise, Taiwanese employees holding the position of most managers. In terms of salary, Taiwanese employees is far higher than mainland employees. Bonus share out bonus, or the end of the draw, the mainland workers will only a little cash reward, while Taiwanese employees usually send shares directly. Assistant teacher this job, for example, Chinese employees salary at around 2500, Taiwanese employees receive 6000, wage gap at about 1.5 times. Therefore, the mainland workers are suffering from huge unreasonable treatment.

\subsubsection{Employees "twisted", reversed transmission enterprises to extend the overtime}

According to the 2013 China statistical yearbook of labor statistics, the Chongqing manufacturing class staff work up to 49 hours a week on average, while in foxconn employees are "forced" to take a day off every week, work up to 60 hours a week, so high strength work hinders young employees in the pursuit of the spirit level. Indeed, whether should let the enterprise reduce work overtime of time, give employees have more time to rest? Employees for enterprise is not proved "ungrateful".Foxconn through continuous optimization of IE, trying to improve the production efficiency of the method to reduce the overtime hours employees, and make the limit overtime overtime control means. Employee's response, is in the afternoon on October 8, gathered at the gate of the pearls in the west wing of the bonded area customs and strike to protest against the enterprise practice, let them to reduce the overtime. Such logic approximate crazy, how can someone volunteered to work overtime. Revision, overtime to shorten the essence of which is to reduce wages, because electronic enterprise salary mainly consists of base salary and overtime, base salary is controlled in 2000 yuan, usually by high strength overtime pay up to 3000 yuan of above, the highest peak can break through 4000 yuan. Such wages constitute make employees had to work overtime to increase their income. Because the basic salary after deduction of social insurance, accommodation, meals, etc, is difficult to meet the living expenses of young employees.

\subsection{The main problems of electronic enterprise labor relations of root cause analysis}

\subsubsection{Electronic enterprise labor relations problems directly}

From direct reasons, individuals, enterprises, government employees are there are some problems in different degrees. In terms of individuals, most of the young workers, cultural level is low, the general lack of understanding of the related labor laws and regulations, combined with the general lack of the consciousness of safeguard their own lawful rights and interests by trade unions, therefore when labour disputes, often don't know what the proper organization in accordance with the law by rights.

In terms of enterprises, the first, the city of electronic enterprise more enterprises with foreign investment, cultural differences lead to manage conflicts. Second, due to the short-term profit motive, devotion to maximize the profit of capital, ignoring the harmonious labor relations on the basis of long-term development of enterprises, so that the model and the phenomenon of infringing on lawful rights and interests of workers. Third, the enterprise trade union construction is not perfect. According to statistics, foreign investment in Chongqing and Hong Kong and Macao commercial enterprise grass-roots trade union organizations for only 312 , accounting for $0.68 \%$ of the total number of organizations at the grass-roots level in Chongqing, 5.57 million people, trade union membership accounts for $0.87 \%$ of the trade union population. Part of the electronics companies and no trade unions, and Foxconn is the establishment of unions in employee continuous jump "thirteen", to cope with the pressure of public opinion. Most of trade union cadres with the management to conclude labor contract to maintain work inside the enterprises, so that in accordance with the law rights once encroached on the interests of the owners, the hard to avoid some trade union cadres have been remove the trouble back at home of labor contract, so difficult to get rid of the dependence on the operator, the union for the worker, just floating on the surface of the festival gifts etc. 
From the government level, at present our country for labor relations and disputes with applicable laws and regulations concerning foreign affairs or omissions or the lack of operability, at the same time, the government to foreign investment, in the aspect of policy to investors have a lot of bias, and investors are standing in a position, ignore the protection of laborers' legitimate rights and interests, so that the partial even contributed to some foreign enterprise employee's illegal behavior. In economic development while ignoring the behind not harmonious labor relations.

\subsubsection{Electronic enterprise labor relations problems of indirect reason}

China is absolutely huge labor resources, 15-64 working-age population will peak in 2014 at the age of 997 million. Chongqing 15-64 - year - old working population accounts for the proportion of the population of permanent residents in the city in recent years has been rise, see table 1.Already exceeds the demand of a line workers, due to the public services such as education resource configuration is not reasonable factors, such as the skill level is not high, which makes them more vulnerable, and may be forced to give up some of their legitimate rights and interests, to accept the harsh conditions of the enterprise operator, only take passive resignation, this situation is restrict and affect the enterprise labor relations coordination pattern of market supply and demand.

According to table 1, Chongqing turning points available for labor force, labor force will shift from unlimited supply for relative balance, then face fewer labor absolute, is Chongqing labor factors from the advantage of industry transfer into a bottleneck factor of industrial transfer, affects the subsequent development of electronics companies.

Table 1, 2010-2013 the proportion of working age population change trend in Chongqing

\begin{tabular}{|c|c|c|c|c|}
\hline year & $\begin{array}{l}\text { The population of } \\
\text { permanent residents } \\
\text { (ten thousand) }\end{array}$ & $\begin{array}{l}\text { Population aged 15-64 } \\
\text { (ten thousand) }\end{array}$ & $\begin{array}{l}15-64 \text { - year - old } \\
\text { population accounts for } \\
\text { the proportion of the } \\
\text { population of } \\
\text { permanent residents in } \\
\text { the city of variation } \\
(\%)\end{array}$ & $\begin{array}{l}15-64 \text { - year - old } \\
\text { population accounts for } \\
\text { the proportion of the } \\
\text { population of } \\
\text { permanent residents in } \\
\text { the city of variation } \\
(\%)\end{array}$ \\
\hline 2010 & 2884.62 & 2061.00 & 71.45 & 1.89 \\
\hline 2011 & 2919.00 & 2088.25 & 71.54 & 0.08 \\
\hline 2012 & 2945.00 & 2113.04 & 71.75 & 0.21 \\
\hline 2013 & 2970.00 & 2130.08 & 71.72 & -0.03 \\
\hline
\end{tabular}

\section{Electronics companies to establish harmonious labor} relations

\subsection{Give play to the role of policy guidance, guide the reasonable development of labor dispatch}

Considering the labor dispatching in satisfy the business enterprise positive role of temporary work demand, the form of employment will also long existing in the labor employment system in our country, the government should strive to guide the labor dispatch back to the original meaning in the form of labor employment supplement. First of all, through the implementation of administrative licensing system, greatly improve the labor dispatching business qualification threshold. Second, intensify the supervision and inspection, the organization to carry out the labor dispatching unit to comply with the labor contract law is special inspection, strictly investigate illegal actions in labor dispatch. Guide development and strictly punish illegal activities in parallel, equilibrium the parties rights and obligations, balance the interests of the relations 
between the parties.

\subsection{To strengthen the construction of trade union organizations}

To strengthen the construction of trade union should pay attention to the following several aspects: first, ensure that the union of independent subject qualification and property rights, to reduce the attachment of the enterprise. Strengthen the communication and the government, strive for the support from the government, set up trade unions and enterprises peer status. Second, to strengthen the construction of their own quality and team construction. Strive to improve the work ability of trade unions and collective bargaining ability, in order to avoid the collective contract become a mere formality, alone in the face of the laws and regulations and formal, in various electronic inspection is formulated on the basis of the actual collective contract, The migrant workers and labor dispatching work organized into trade unions, establishing and perfecting the enterprise trade union organizations.

\subsection{Enterprise change management ideas, positive social responsibility}

Current and future development in China, rising labor costs is the trend of The Times, some scholars in labor and social security policy simulation system predicts that by 2050, the total labor force decline is an inevitable trend. "Labor shortage" phenomenon in the coastal area is an example. Enterprises should correctly understand the current situation, the attempted to make a profit by holding down wages and welfare of times will pass, the management to face up to the internal mediation, face up to collective bargaining, which is a kind of to achieve win-win cooperation of both sides of labour and capital means of adjusting labor relations. By establishing the atmosphere of mutual trust to achieve peaceful enterprise, enterprise management and human resource department should as far as possible will dispute resolve within the enterprise, rational compromise to deal with the problem, don't hold opposite hostile attitude towards the interests of the workers reasonable demands. Change the concept of the enterprise benefit and employee "insulation" let employees participate in enterprise management and decision-making, improve the treatment, can fundamentally solve the reversed transmission enterprise employees to extend the phenomenon of overtime, enhance staff's sense of belonging and identity, promote enterprise development and social stability.

\subsection{The government set up the development philosophy of "with the staff for this"}

Although practice market economy in our country, but the government's leading role, the government's policy towards the status of directly affects the benefit groups. In the modern machine under the control of the mass production, employees have a common labor skills is vulnerable groups, but in labor-intensive enterprises play an important role, ensure the normal operation of the production line, is the base of production was achieved. Chongqing as industrial transfer to undertake is a long-term project, the government should use a long-term view to look at the development of economy, with the staff for this, attach importance to the role of the harmonious labor relations, not only immediate economic benefit and political achievements.

\section{CONCLUSIONS}

Harmonious and stable labor relations is an important premise of long-term development of enterprises, but as you see, electronic enterprise labor relations appear all sorts of problems. The government and enterprise should change the notion of myopia, assume their own responsibilities. Valuing feelings and development of employees, combining closely with the personal goals and enterprise development goals, in order to common development.

\section{References}

[1]http://wjj.cq.gov.cn/zhzx/68417.htm

[2]http://www.cqtj.gov.cn/html/tjsj/tjgb/11/12/5847.

html

[3] http://wjj.cq.gov.cn/jjyx/68404.htm 
[4] http://wjj.cq.gov.cn/zhzx/68432.htm

[5]Chongqing statistical yearbook 2009, 2014

[6]Wu,X.-W., Wang,C.. Foundry enterprise labor relations

to explore humanistic management environment for foxconn - for example [J]. Journal of dalian maritime university. 2011 (5)

[7]Lv,J.-M., Li,G., Wang,L.. About led the development of our labor dispatch specification [J]. Journal of Shandong human resources and social security, 2014-1

[8]2013 China human resources and social security yearbook (work roll). China labor social security publishing house

[9]Zhang,X.-J.. Concerning the current situation of collective bargaining, and mess [J]. Journal of law research, 2014 (5)

[10]China labor statistics yearbook 2011

[11]Lv,H., Sun,S.. Flexible employment market under the new situation of the labor force supply and demand analysis [J]. Journal of Hebei normal university, 2014 (3)

[12]Beijing municipal labor and social security law. Labor relations and labor dispute status quo and prospect of [C]. China legal system publishing house, 2013

[13]People club department is sent. About advancing the implementation of the collective contract system of crucial plan notice. 2014

[14]Zhang,Y.-M., Han,W.. 2010-2050 in our country labor supply forecast and analysis [J]. Journal of Guangxi economic management cadre institute. 2014 (1) 